INTERNATIONAL MONETARY FUND

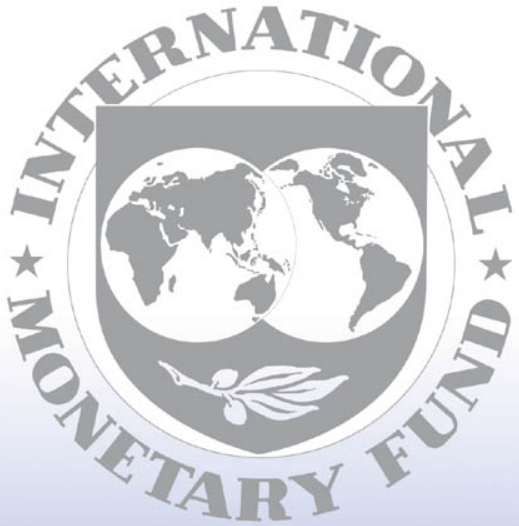

Staff

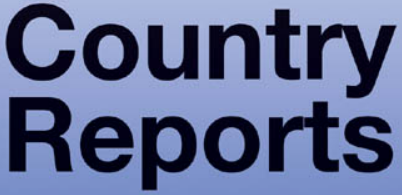


(1) 2001 International Monetary Fund

October 2001

IMF Country Report No. 01/198

\section{France: Selected Issues - Labor Market Developments and Wage Moderation in France in the 1990s}

This Selected Issues report on France was prepared by a staff team of the International Monetary Fund as background documentation for the periodic consultation with the member country. The views expressed in this document are those of the staff team and do not necessarily reflect the views of the government of France or the Executive Board of the IMF.

The policy of publication of staff reports and other documents by the IMF allows for the deletion of market-sensitive information.

To assist the IMF in evaluating the publication policy, reader comments are invited and may be sent by e-mail to Publicationpolicy@imf.org.

Copies of this report are available to the public from

international Monetary Fund • Publication Services

$70019^{\text {th }}$ Street, N.W. * Washington, D.C. 20431

Telephone: (202) 623-7430 • Telefax: (202) 623-7201

E-mail: publications@imf.org Internet: http://www.imf.org

Price: $\$ 15.00$ a copy

\section{International Monetary Fund Washington, D.C.}




\section{INTERNATIONAL MONETARY FUND}

FRANCE

\section{Selected Issues}

\section{Labor Market Developments and Wage Moderation in France in the 1990s}

Prepared by Marcello Estevão

Approved by the European I Department

October 3,2001

Contents

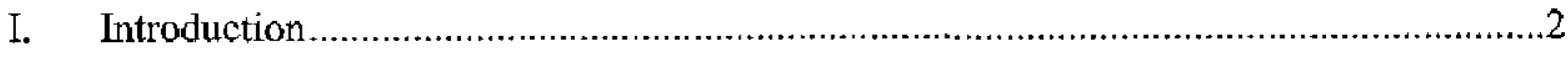

II. Overview of French Labor Market Performance in the 1990s ......................................

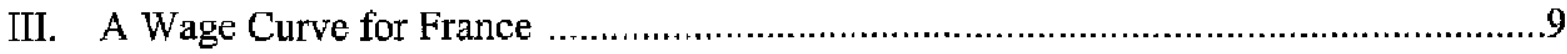

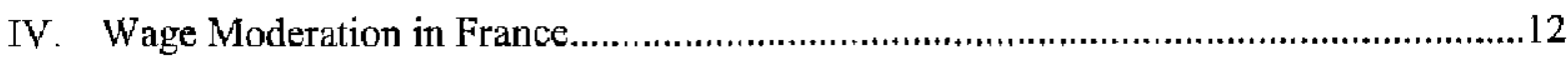

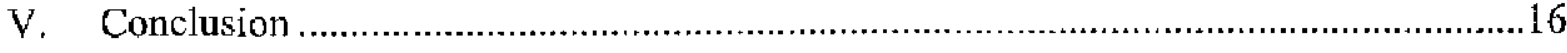

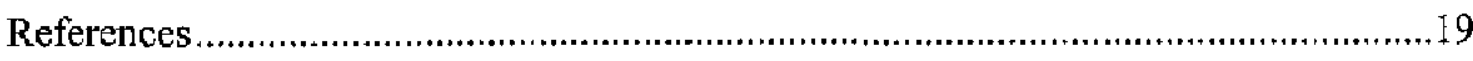

Figures

1. Employment and Unemployment Rates by Gender and Age Groups .............................

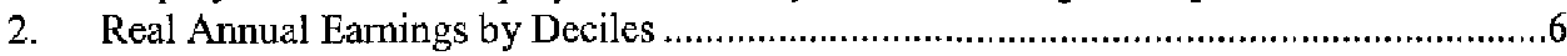

3. $\quad$ Real Hourly Wages by Deciles .............................................................................

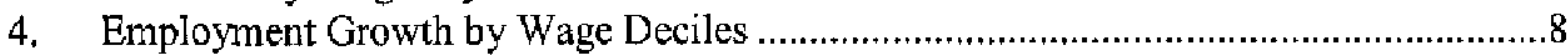

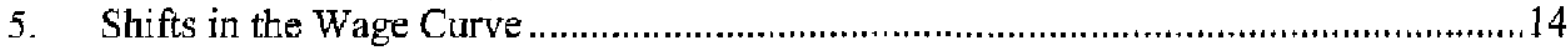

6 $\quad$ Labor Share and Replacement Rates ................................................................15

Tables

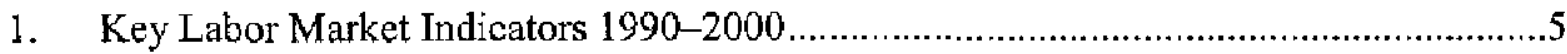

2. Estimate of the Wage Curve (Equation 4) ............................................................11

3. Hourly Wage Growth in the Nonfarm Business Sector ..............................................13

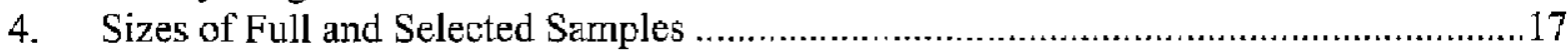

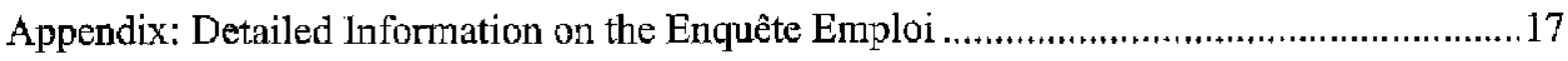




\section{INTRODUCTION}

1. The French economy grew at robust rates between 1997 and 2000 without signs of price acceleration. Labor market performance was also strong with unemployment rates falling from 12/4 percent in mid-1997 to $8 \frac{1}{2}$ percent in May 2001 and employment rising particular]y sharply during the same period. The most recent expansion generated 400,000 additional jobs on average each year; substantially more than the 1987-1989 expansion which showed an average annual employment increase of 270,000 individuals. Taking into account that average output grawth between 1997 and 2000 was 0.8 percentage point below the average growth at the end of the $1980 \mathrm{~s}$ - and assuming a given level of labor productivity-the recent recovery should have produced about 100,000 fewer jobs than the previous one. As discussed in PisaniFerry (2000), part of the overall difference in employment growth between both periods can be explained by the effect of government policies which aimed at reducing unemployment rates mainly among less skilled workers. However, given current estimates for these effects, about half of the better employment performance in the latter period remains unexplained. ${ }^{1}$

2. Another remarkable aspect of the $1990 \mathrm{~s}$ is the moderate wage growth in France in contrast with the well-documented large wage increases during the late 1970 s and the first half of the $1980 \mathrm{~s}^{2}$ Once the effects of changes in the composition of the labor force and variations in the unemployment rate are taken into account, real hourly wages have grown much less than productivity throughout the $1990 \mathrm{~s}$. This result is all the more notable given the overall increase in income tax rates throughout the decade (despite the recent cuts) and the resulting lower takehome pay. Also, ancillary evidence on changes in unemployment benefits replacement rates, the intensity of labor in the production process, and labor market regulations do not seem to explain the wage behavior.

3. This paper provides an explicit theoretical and quantitative framework to assess the role of wage moderation in reducing unemployment in France. Wage moderation is defined here as an increase in unions 'preference for employment or an overall reduction in unions' bargaining power. It complements the analysis of the cross-country background paper "Job-rich growth in Europe" by estimating a microeconomic model on data from the French employment survey (Enquête Emploi). The paper defines a theoretical framework based on the bargaining models described in Layard et al (1991). This framework is used to estimate and interpret a "wage curve" in which individual pay is linked to the local unemployment rate controlling for

\footnotetext{
${ }^{\mathrm{I}}$ Pisani-Ferry (2000) provides an overview of all the studies measuring the effect of recent government policies on employment. His analysis is limited to the period from 1997 to 1999 but an update through 2000 would produce similar conclusions. Among the most important policy changes are the cuts in social security contributions for firms hiring low-wage earners since 1993 and the three laws aiming at the reduction of the standard workweek to 35 hours enacted after 1996.
}

${ }^{2}$ See Blanchard (1997) and Decressin et al (2001). 
observable individual characteristics, a paradigm set by Blanchflower and Oswald (1994). The econometric exercise points to a significant degree of wage moderation during the 1990s consistent with a decline in labor union bargaining power or an increase in society's preference for employment over wages. Section II provides some stylized facts of French labor market developments in the 1990s. Section III presents the theoretical framework and the econometric estimation of the wage curve for France. Section IV uses these results to derive measures of economy-wide wage moderation. Section $\mathrm{V}$ concludes.

\section{Overview of French Labor Market Performance in the 1990S}

4. A compilation of data from the Enquête Emploi shows that unemployment rates have declined steadily since the 1997 peak (Table 1). ${ }^{3}$ By 2000, the proportion of the population between 15 and 64 years of age that is employed - the employment rate-reached 61 percent, the largest value in the decade albeit still low by international standards. ${ }^{4}$ The proportion of full-time workers in total employment declined from 87 percent in 1990 to 82 percent in 2000 , a result of increased acceptance of part-time arrangements. Average hours of work per week decreased steadily throughout the decade. The two largest annual declines in average hours of work occurred in 1999 and 2000 even as economic activity expanded vigorously, reflecting the various workweek reduction laws introduced since 1996. A breakdown of employment by gender shows a slightly larger growth in the employment rate among women since 1994 (Figure 1). Youth employment increased appreciably over 1997-2000 and the employment rate for this group edged up after hitting a trough in 1997. The reduction in the unemployment rate has been larger among younger workers compared to prime working-age and older individuals.

5. More important for the purpose of this paper, real hourly wages increased 6 percent during $1990-2000$ or at an average annual rate of 0.5 percent; much below total factor productivity growth in France adjusted for the labor share (about 1.4 percent per year), a measure of labor augmenting technical progress. ${ }^{5}$ Furthermore, most of this growth (5 percentage points) occurred during 1990-1993. This latter observation is associated with a contemporary change in the composition of the labor force in France: the recession years pushed less-skilled workers (and, thus, low-wage earners) out of the labor market, raising

\footnotetext{
${ }^{3}$ The individual sampling weight is used in the statistical analysis to make it representative of the whole population.

${ }^{4}$ See OECD (2001). For instance, employment rates in Germany (66.3 percent), the U.S. (74.1 percent) and the Netherlands ( 72.9 percent) were much larger than in France. Italy (53.4 percent) and Spain (56.1 percent) continue to trail France. The OECD average was 65.7 percent.
}

${ }^{5}$ Technological progress is assumed to be labor augmenting (Harrod neutral) to allow for balanced growth in a dynamic setup. The measure proposed here is a proxy for this variable and has also been used in Blanchard (1997). 
Figure 1. France: Employment and Unemployment Rates by Genderand Age Groups $(P \in \mathbf{r} \in \mathrm{e} t)$

Employment Rateby Gender
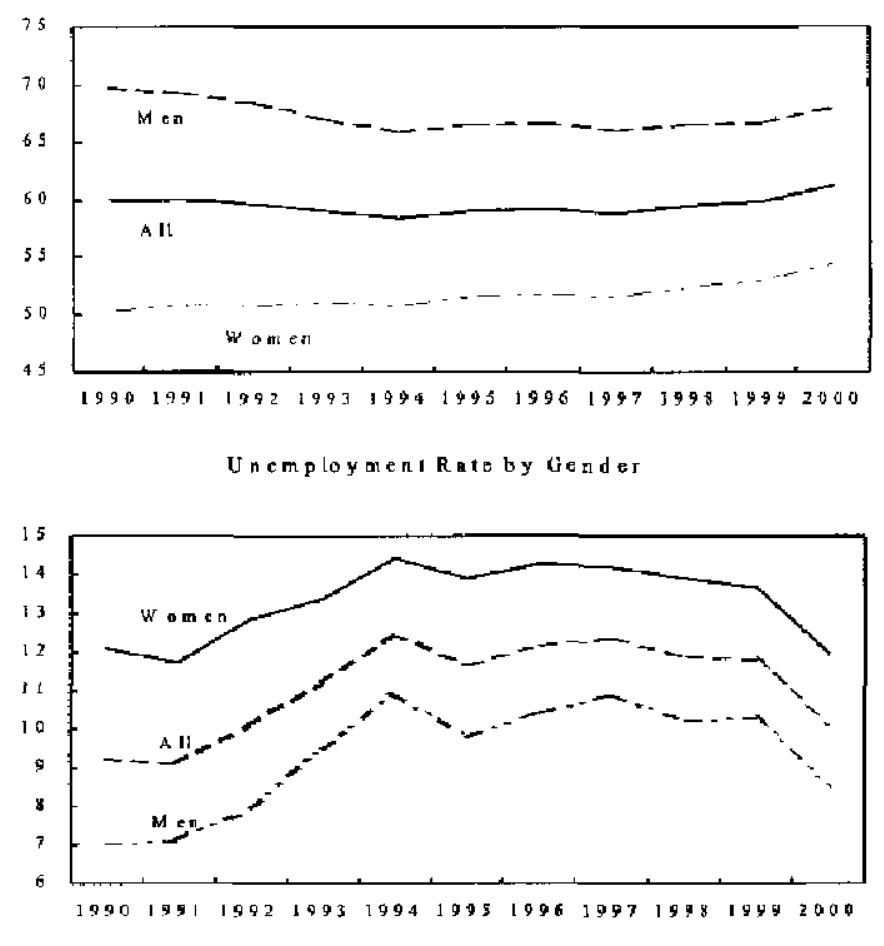

Employment Rateby Agroup
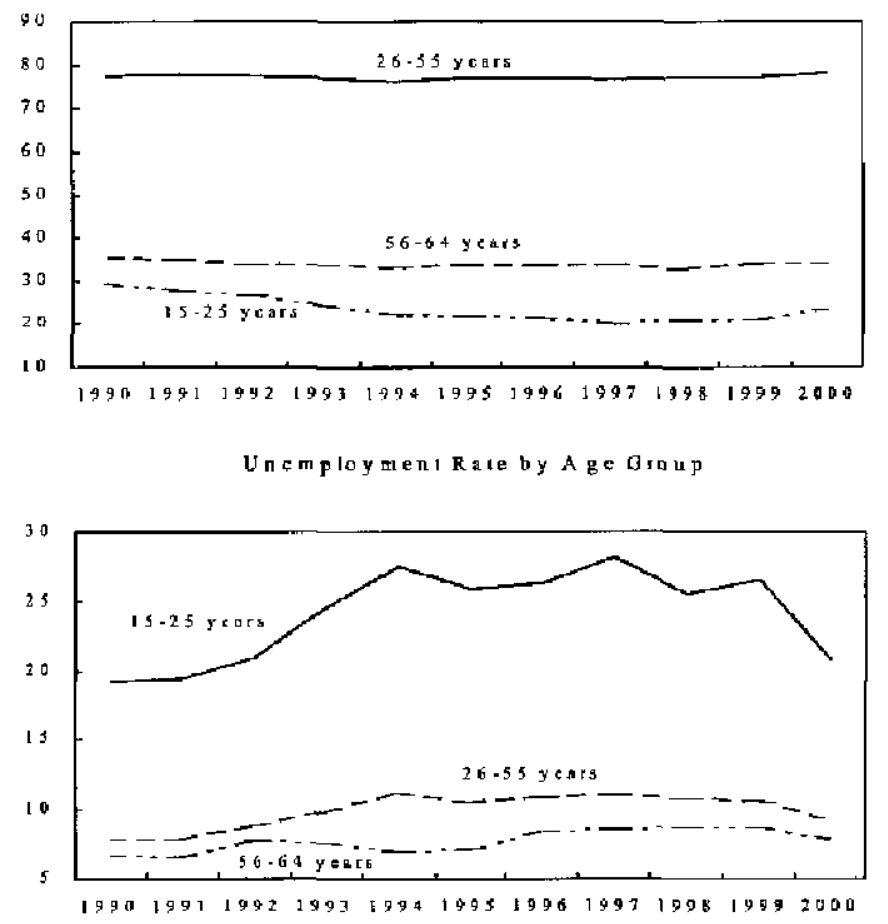
average wages. The growth rate of real hourly wages fell below the trend growth rate of total factor productivity during the recovery from 1994 onwards. Real annual earnings increased at an even lower rate than real hourly wages throughout the decade.

Table 1. France: Key Labor Market Indicators, 1990-2000 (Weighted means ${ }^{1}$ )

\begin{tabular}{ccccccc}
\hline Year & $\begin{array}{c}\text { Real annual } \\
\text { earning }^{2} \\
(\%)\end{array}$ & $\begin{array}{c}\text { Real hourly } \\
\text { wage }^{2} \\
(\%)\end{array}$ & $\begin{array}{c}\text { Weekly } \\
\text { hours } \\
\text { worked }\end{array}$ & $\begin{array}{c}\text { Employment } \\
\text { rate } \\
(\%)\end{array}$ & $\begin{array}{c}\text { Full time } \\
\text { employed } \\
\text { rate }(\%)\end{array}$ & $\begin{array}{c}\text { Unemployment } \\
\text { rate } \\
(\%)\end{array}$ \\
\hline 1990 & --- & -- & 39.9 & 59.9 & 87.1 & 9.2 \\
1991 & 2.0 & 1.0 & 40.3 & 59.9 & 86.9 & 9.1 \\
1992 & 3.0 & 2.0 & 40.1 & 60.0 & 86.3 & 10.1 \\
1993 & 2.0 & 2.0 & 39.9 & 59.0 & 85.0 & 11.2 \\
1994 & -2.0 & -2.0 & 39.9 & 58.3 & 84.0 & 12.5 \\
1995 & -1.0 & -1.0 & 39.6 & 59.0 & 83.2 & 11.7 \\
1996 & -1.0 & -1.0 & 39.6 & 59.2 & 82.6 & 12.2 \\
1997 & 0.0 & 1.0 & 39.2 & 58.8 & 82.0 & 12.4 \\
1998 & 0.0 & 1.0 & 39.3 & 59.4 & 81.6 & 11.9 \\
1999 & 1.0 & 1.0 & 38.8 & 59.8 & 81.9 & 11.8 \\
2000 & -1.0 & 2.0 & 38.4 & 61.1 & 82.4 & 10.1 \\
\hline
\end{tabular}

Source: Authorities, Enquête Emploi; and Fund staff estimates.

'The means are weighted by individual sampling weights.

${ }^{2}$ Real earnings and wages were obtained by deflating the respective nominal variables by the Consumer

Price Index (CPI).

6. The distribution of wage and earnings growth has not been uniform across deciles (Figure 2). The bottom deciles of the earnings distribution have experienced less growth than the upper deciles over the entire sample period. However, there was a greater increase in the lower deciles during the high-growth period (1997-2000). Unlike total labor earnings, growth in hourly wages at lower deciles has been stronger during the 1990s as shown in Figure 3. Underlying this difference is the stronger negative trend in average hours of work among lowskill individuals throughout the decade. Changes in hourly wages over the different stages of the business cycle point to even larger increases in real hourly wages of low-skill workers during the high-growth period. A breakdown in employment growth by wage deciles also suggests important composition changes (Figure 4). In particular, employment growth during the decade was stronger in lower wage deciles. The larger growth of real hourly wages and employment at the lower tail of the wage distribution is consistent with a change in regime in the 1990s toward an expansion of labor demand for low-skill workers-a stated objective of government policies implemented through several cuts in employers' social security contributions. The implied result is diminishing wage dispersion in France mainly since 1997.

7. The development of these key labor market variables points to the importance of using microeconomic data to better analyze labor market performance. In particular, the $1990 \mathrm{~s}$ seemed to have witnessed significant changes in the composition of work hours and work quality. 
Fignre 2. France: Real Annul Earnings by Deciles"

(Percent change)
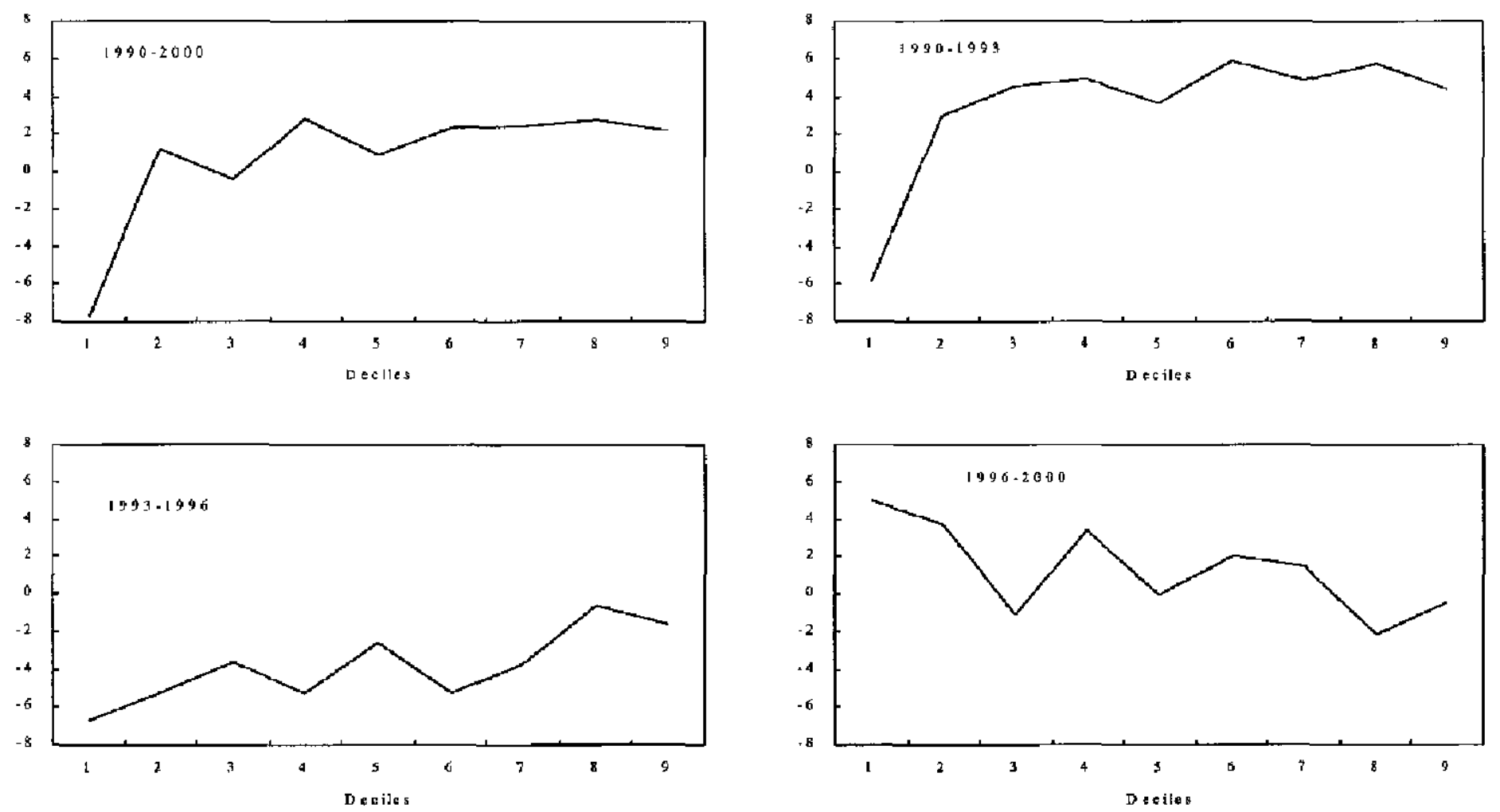

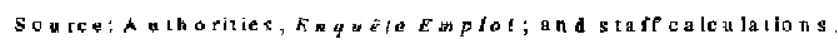

In formation for the tenth decile was onjtied due to lape volatility of extreme observations. 
Figure 3. France: Real Hourly Wages by Deciles" (Percent change)
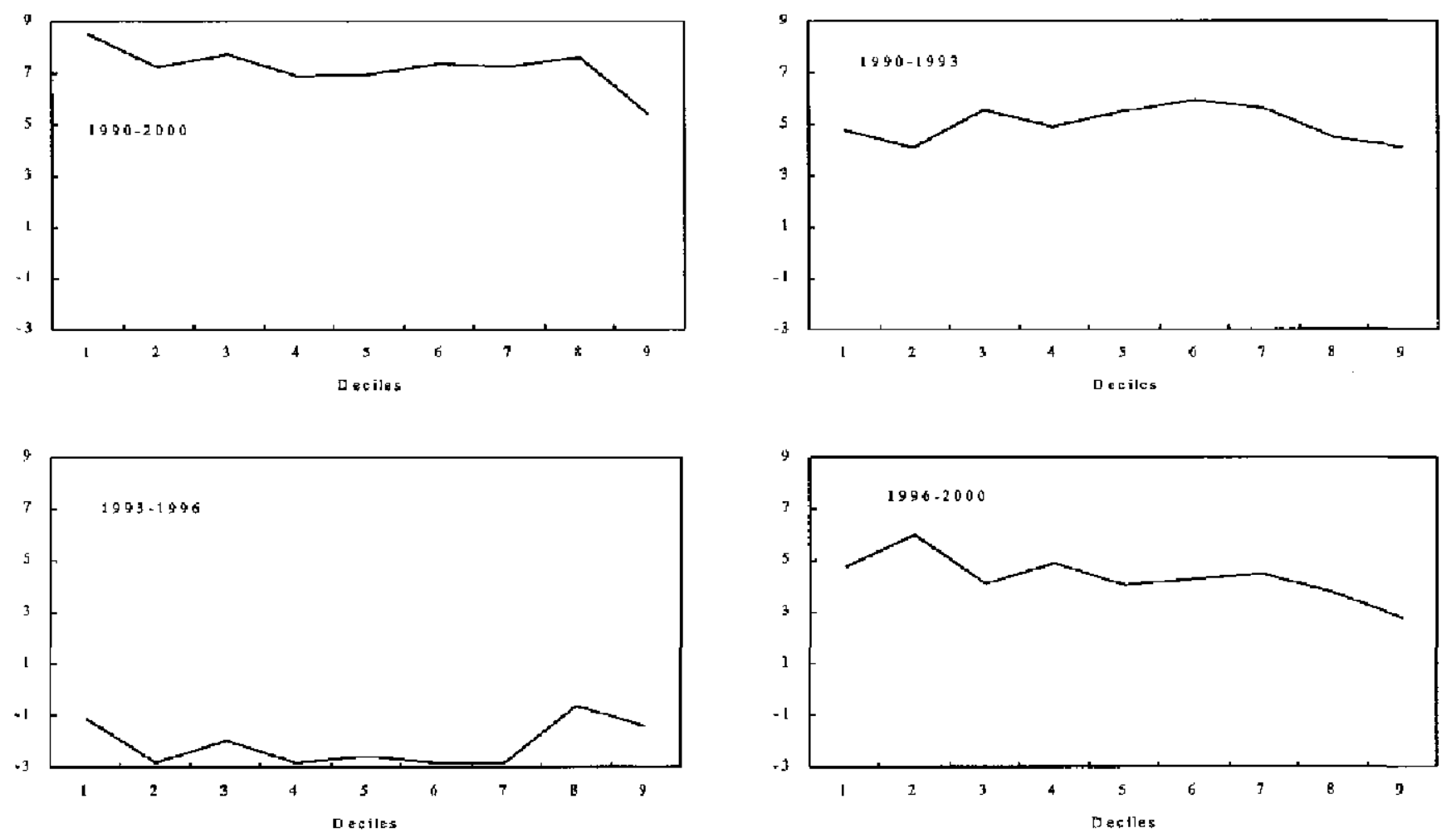

Source: A uthorities, Enquête Emploitiand authars'calculations.

"Information forthe tenth decile was omitted due to large valatility ufueteme observations 
Figure 4. France: Employment G rowth by Wage Deciles" (Percent changc)
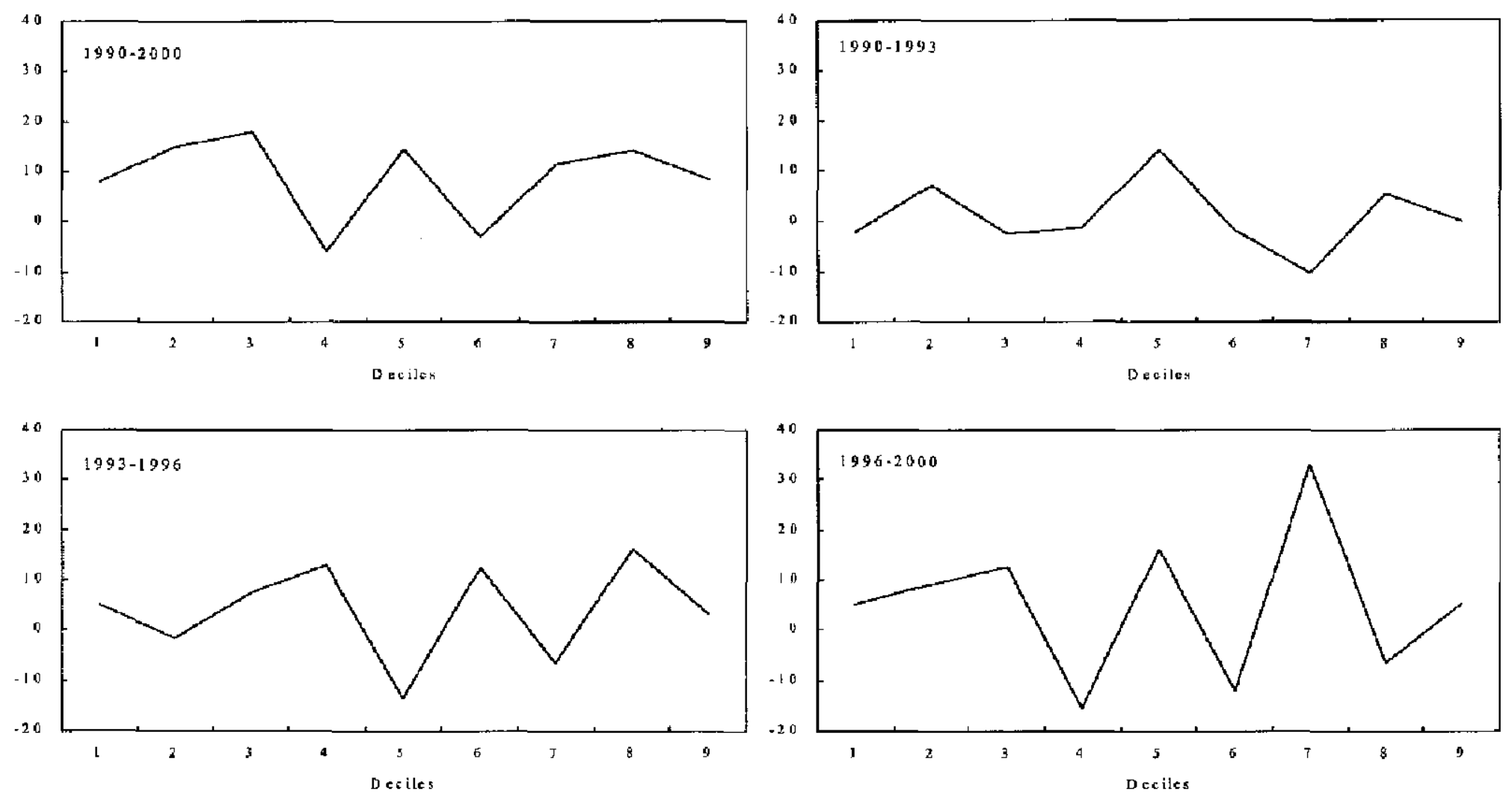

Souree: A uthoritieg, Enquéte $E m p l o i$; and slalf estjmates

1" Last decile omitted to conform with Figures 2 and 3 


\section{A Wage Curve for France}

8. In modeling the functioning of the French labor market, this paper adopts the right-tomanage model in which firms and unions bargain over wages but firms set employment unilaterally. Firms are assumed to determine employment by maximizing profits while unions take into consideration the employment effects when negotiating the wage. Such a model generates a relationship between wages and unemployment of the following type:

$$
\frac{W}{B}{ }^{*} \tau=f(m, u), f_{m}>0 \text { and } f_{u}<0
$$

where, $W, B$ and $\tau$ stand, respectively for the hourly wage, the income a worker would receive if unemployed, and the tax wedge between labor income and unemployment income; $m$ is a structural parameter determining the position of the wage curve and its steepness; $u$ is the unemployment rate.

9. In words, for a given rate of unemployment, wages will depend on how large the unemployment income (corrected for its relative tax liabilities) is and on the position of the wage curve, a finction of $m$. Ceteris paribus, the larger the unemployment income the bolder will be wage demands because in case of disagreement during the bargaining process the alternative scenario of being unemployed becomes less unatractive. When the unemployment rate increases, the probability of not finding a job also increases and wage demands will be more subdued. Whenever workers' bargaining power becomes stronger, or whenever workers give more value to employment levels vis-à-vis higher wages, the parameter $m$ decreases and wages will be lower for a given rate of unemployment. This is what this paper defines as "wage moderation." Changes in production technology and product market conditions may also affect the relationship between wages and unemployment through variations in the parameter $m$. If technology is more labor intensive, wage demands will be weaker because workers will incorporate the stronger effect of higher wages on employment. The same holds if the elasticity of product demand is larger. ${ }^{6}$

10. Equation (1) can be estimated using microeconomic information from the Enquête Emploi, the annual labor force survey for France (see Appendix). A log-linear version of equation (1) is:

$$
\ln w_{i t}=a+X_{i t}^{\prime} b+g \ln u_{r t}+d_{t}+d_{r}+e_{t t}
$$

\footnotetext{
${ }^{6}$ Estevão and Nargis (2001) spell out a standard bargaining model with these characteristics that is formally equivalent to the basic framework discussed in Layard et al (1991). Alternative models postulating that firms and workers bargain over wages and employment ("efficient bargaining models") would suggest that only workers" preferences and relative bargaining power affect the parameter $m$. But the right-to-manage model seems to be a more realistic rendition of how wage bargaining takes place in practice.
} 
where $\ln$ refers to natural $\log , w_{i t}$ is the hourly wage rate of individual $\mathrm{i}$ in year $\mathrm{t}, X_{i t}$ is a vector of individual observable characteristics (gender, age, marital status, number of children, education, occupation, industry of work and employment status-full time or part time), $u_{r}$ is the unemployment rate in region $\mathrm{r}$ at year $\mathrm{t}, d_{\mathrm{t}}$ and $d_{r}$ are respectively temporal and regional dummies, and $e_{i t}$ is an i.i.d. error term.

11. When estimating the relationship between unemployment and wages from survey data some econometric issues need to be dealt with. In particular, it is necessary to guard against possible inefficient estimation that would result from the existence of covariance among individuals which is not entirely attributable to either their measured characteristics or the local unemployment rate (Moulton, 1986, 1990). To address this concern, the two-step estimation approach proposed by Card (1995) is used. In a first step, the following equation is estimated:

$$
\ln w_{i t}=a+X_{i t}^{\prime} b+\sum_{r, t} \omega_{n t} \cdot 1_{\text {Reglon }=r} \cdot 1_{T 7 m e=t}+e_{i t}
$$

This equation excludes the local unemployment rate, but includes interactive region and time dummies, whose coefficients can be interpreted as the average regional wage in time t once individual characteristics are controlled for. In a second step, the adjusted wage variable is regressed on time and region effects as well as on the regional unemployment rate:

$$
\omega_{r t}=c+g \ln u_{r t}+d_{t}+d_{r}+e_{r t}
$$

To address possible simultaneity bias in equation 4 the lagged unemployment rate is used as

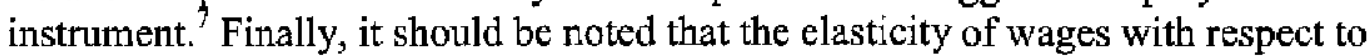
unemployment is not necessarily time-invariant. However, lack of cross-sectional variation in the data prevents sufficiently precise yearly estimates of this elasticity to test for its time variance while at the same time including shifts in the intercept $c$-represented by $d_{i}{ }^{8}$

12. For the actual estimation of the system of equations (3) and (4), the wage variable used was the individual monthly salary net of social security contributions during the month immediately before the survey interview divided by 4.33 times the actual weekly hours of

\footnotetext{
${ }^{7}$ The bias results from the possibility that higher wages cause lower labor demand and thus a higher rate of unemployment.

${ }^{8}$ Estevão and Nargis (2001) report the results of different specifications for equation (4), including the introduction of higher-order polynomials for the unemployment rate and a dynamic specification with lagged wages as a regressor. Those specifications did not improve upon the simpler setup described here.
} 
work during the week immediately before the survey. ${ }^{9}$ No information is available on individuals' tax liability or income when unemployed but part of it is likely picked up by the dummies representing individual characteristics. The selected sample was divided into three age groups of $15-25,26-55$ and $55-65$ and interacted with the education variable to proxy for experience in the wage regression. Other control variables used in the estimations were: six education levels, seven non-farm econoraic sectors excluding the public sector (manufacturing, utilities, construction, retail trade, transport, financial services, and real estate), the full-time status of an employee, 28 occupational categories (exclucing farm employment and military services) and 21 regions of residence. Self-employed workers were also excluded from the sample. The final sample produced 235,545 pooled cross-sectional observations from 1990 to 2000. Apart from the regional and time dummies, regional unemployment rates were added to the list of explanatory variables in the second-step equation (4).

Table 2. France: Estimate of the Wage Curve (Equation (4))

\begin{tabular}{|c|c|c|}
\hline & $\begin{array}{r}\text { Dependent variable: Nom } \\
\text { for Individu }\end{array}$ & $\begin{array}{l}\text { g Hourly Wage Adjusted } \\
\text { racteristics }{ }^{1}\end{array}$ \\
\hline Independent variables & Ordinary least squares & Instrumenta] variable $^{2}$ \\
\hline Regional unemployment rate & $\begin{array}{l}-0.0298 * \\
(0.0141)\end{array}$ & $\begin{array}{c}-0.0989^{* * *} \\
(0.0295)\end{array}$ \\
\hline Time and regional dummies & jointly significant** & jointly significant** \\
\hline
\end{tabular}

13. The instrumental variable (IV) estimate of the elasticity of hourly wages with respect to the unemployment rate is -0.1 , the same value Blanchflower and Oswald (1994) found for

\footnotetext{
${ }^{9}$ All the regressions were replicated using annual earnings data-a less theoretically desirable variable but nonetheless another measure of labor income-to check for the robustness of the results. This replication produced nearly identical results to those obtained using hourly wages. For details see Estevão and Nargis (2001). The results using annual earnings are also more directly comparable to the results in Blanchflower and Oswald (1994) for other countries, and in Gianella (2000) for France. The latter work uses different methodologies than the one presented here and a matched employer-employee panel data in the private sector from the Déclarations Annuelles des Salariés (DAS) and Echantillon Démographique Permanent (EDP) for the period from 1984 to 1995, with 1990 excluded.
} 
several other countries. ${ }^{10}$ The smaller estimate (in absolute value) obtained by the OLS procedure is consistent with some simultaneity bias coming from a relationship between wages and unemployment driven by labor demand. The IV estimate indicates that wages are negatively correlated with local unemployment rates, controlling for individual demographic and labor market characteristics and that a doubling of the unemployment rate would be associated with a drop in hourly wages of 10 percent. The time and regional dummies were highly significant.

\section{WAGE MODERATION IN FRANCE}

14. Using the results of the previous section and taking into account changes in the tax wedge and unemployment income there is strong evidence of wage moderation in France during the 1990 s (Table 3) ${ }^{11,12}$ Nominal hourly wages increased about 20 percent between 1991 and $2000 .^{13}$ The time-specific intercepts of equation (4) - which equals the intercept in 1991 plus the coefficient of each respective time dummy-can be interpreted as the nominal hourly wages once composition and unemployment effects are taken into account. Thus adjusted wages increased only 2 percentage points less than the unadjusted series (Table 3, column 2). Taking into account inflation and technology, first, and taxes, second, the final adjusted wage series posted a $16^{1 / 2} 2$ percent decline (Table 3 , column 4). Or, in other words, real hourly wages fell behind productivity, and wage demands were moderate despite an

${ }^{10}$ For a discussion of the full set of results including estimates of equation (3) see Estevão and Nargis (2001).

${ }^{11}$ Shifts in the relationship between unemployment and wages are captured by the coefficients of the time dummies in (4). These shifts can be caused not only by changes in the parameter $m$ in equation (1) but also by changes in aggregate unemployment income and in tax wedges since they were not directly controlled for during the estimation of (4). To account for these latter effects, the estimated intercept for each year was divided by the CPI and by an index measuring technological progress, and corrected for the path of aggregate income tax rates. The technological progress index was measured by accumulating changes in total factor productivity scaled by the labor share. Pure composition effects, changes in the CPI and technological growth are assumed to capture, among other things, changes in income when unemployed. For a discussion of variables affecting individuals' reservation wages or implicit income when unemployed see Blanchard and Katz (1997).

${ }^{12}$ To measure changes in the tax wedge, data on average income tax rates for different types of families from the OECD tax and benefits database were used. Thus, it is implicitly assumed that changes in average income tax rates did not affect after-tax unemployment income.

${ }^{13}$ Because lagged unemployment rates are used as instruments for the estimation of equation (4), the year 1990 is dropped from the sample. 
increase in income tax rates (which, ceteris paribus, should have raised them by about 6 percentage points).

Table 3. France: Hourly Wage Growth in the Nonfarm Business Sector

(Percent change)

\begin{tabular}{ccccc}
\hline Period & $\begin{array}{c}\text { Houtly wage } \\
(1)\end{array}$ & $\begin{array}{c}\text { (a) Adjusted for } \\
\text { composition changes } \\
\text { and the effect of the } \\
\text { unemployment rate } \\
(2)\end{array}$ & $\begin{array}{c}\text { (b) Adjusted for } \\
\text { inflation and } \\
\text { productivity } \\
(3)\end{array}$ & $\begin{array}{c}\text { (c) Adjusted for } \\
\text { changes in average } \\
\text { income taxes } \\
(4)\end{array}$ \\
\hline $1991-1993$ & 9.15 & 8.06 & 3.19 & 2.65 \\
$1993-1996$ & 1.49 & 2.56 & -6.12 & -6.81 \\
$1996-2000$ & 8.51 & 6.70 & -7.58 & -12.68 \\
$1991-2000$ & 20.20 & 18.25 & -10.47 & -16.48 \\
\hline
\end{tabular}

Source: Hourly wages from the Enquête Emploi; and staff estimates of equation (4). Inflation is measured by changes in CPI, INSEE. Technological progress is TFP growth adjusted for the share of labor income, OECD and INSEE. Average income taxes from the tax and benefits database, OECD.

'Column (2) refers to the time specific intercept implicit in the estimate of equation (4).

15. Such a negative trend in the adjusted time-specific intercept of (4) implies that the wage curve shifted downward and that, for a given state of labor demand, unemployment was smaller at each wage level. Figure 5 shows the actual shifts in the wage curve in France during the 1990s defined as the relationship between one minus the unemployment rate and real hourly wages adjusted for productivity and taxes (and changes in the composition of employment); a standard way to present what is sometimes referred to as a "labor supply-like" curve . It is interesting to note that the shift was larger during the latest expansion when the labor intensity of growth seemed to have increased when compared to historic experience.

16. According to the theoretical relationship between wages and unemployment discussed above, this wage moderation can be interpreted as a change in unions' preferences toward employment or a decline in their bargaining power. However, other factors could conceivably produce the same outcome. In particular, technological changes, which in equilibrium are equivalent to changes in the labor share, could cause such a shift. But the broadly unchanged share of labor income in GDP throughout the 1990s suggests an unchanged technology parameter (Figure 6). It is also possible that inflation and productivity growth are imperfect proxies for the income received when unemployed because, for instance, they do not capture institutional changes in unemployment insurance schemes. However, OECD data for gross benefit replacement rates do not point to relevant changes in the ratio of benefits to labor income in the 1990s at least until 1997, the last available data point (Figure 6). The observed shift in the wage curve could have been caused by the process of globalization of production which might have increased product market competition and the elasticity of product demand. Such a development would cause a downward shift in the wage curve because unions would take into account the adverse effects of high wage demands on production costs and, 
ultimately, on the amount produced and sold. It is hard to disentangle this effect from pure changes in unions' preferences and many analysts would place this product market effect together with an overall reduction of unions' bargaining power.

Figure 5. France: Shifts in the Wage Curve

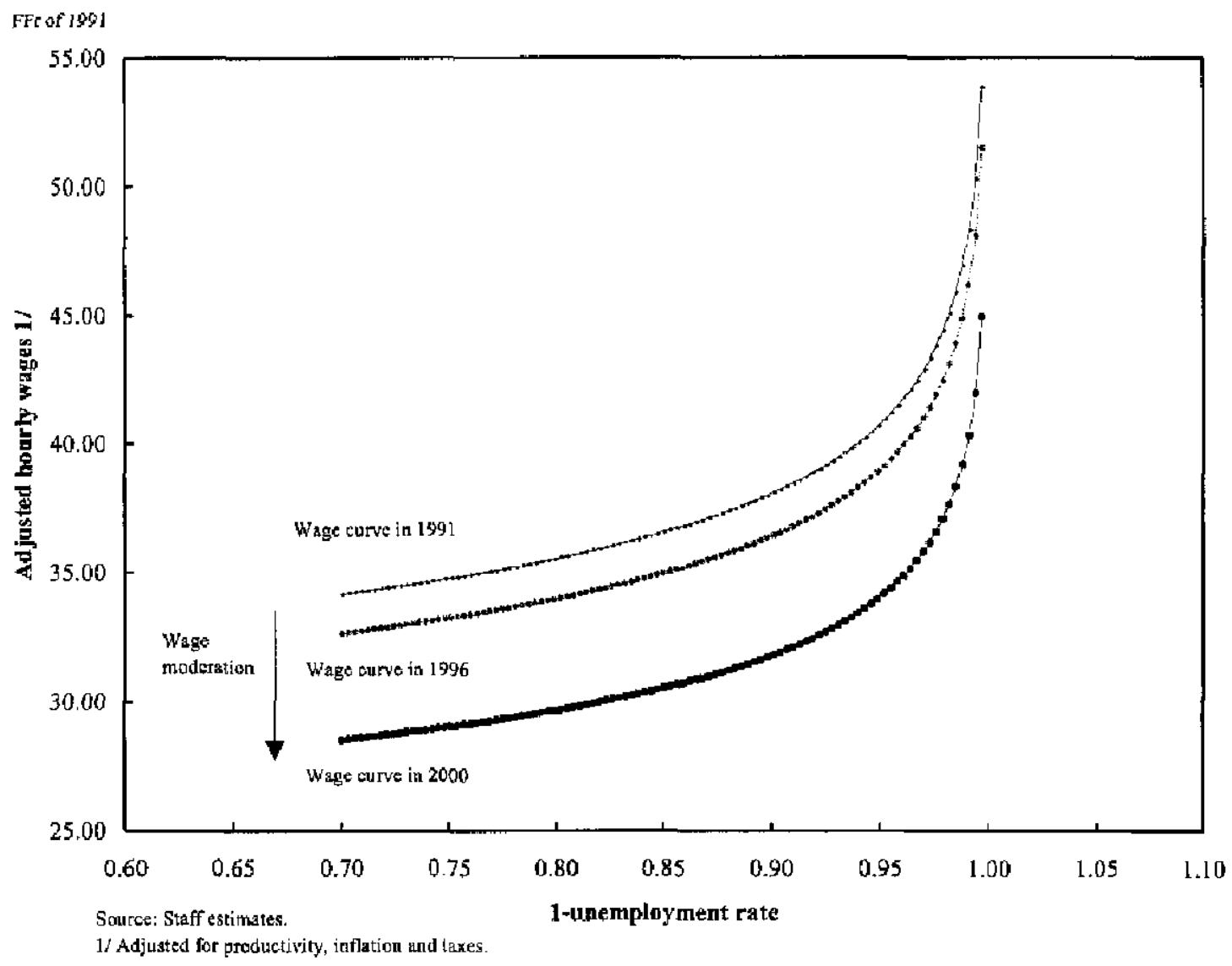


Figure 6. France: Labor Share and Replacement Rates

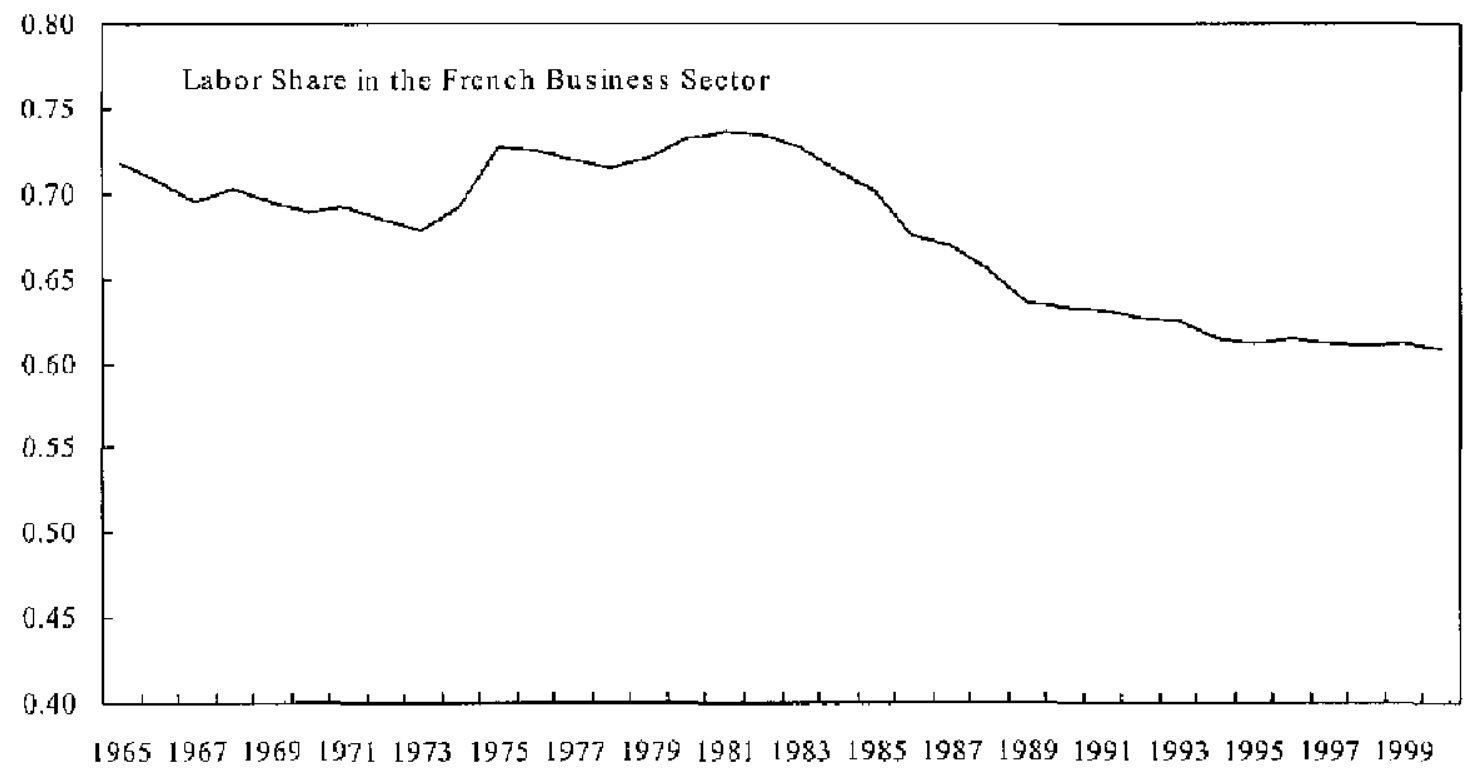

Source: OECD and staff calculations.

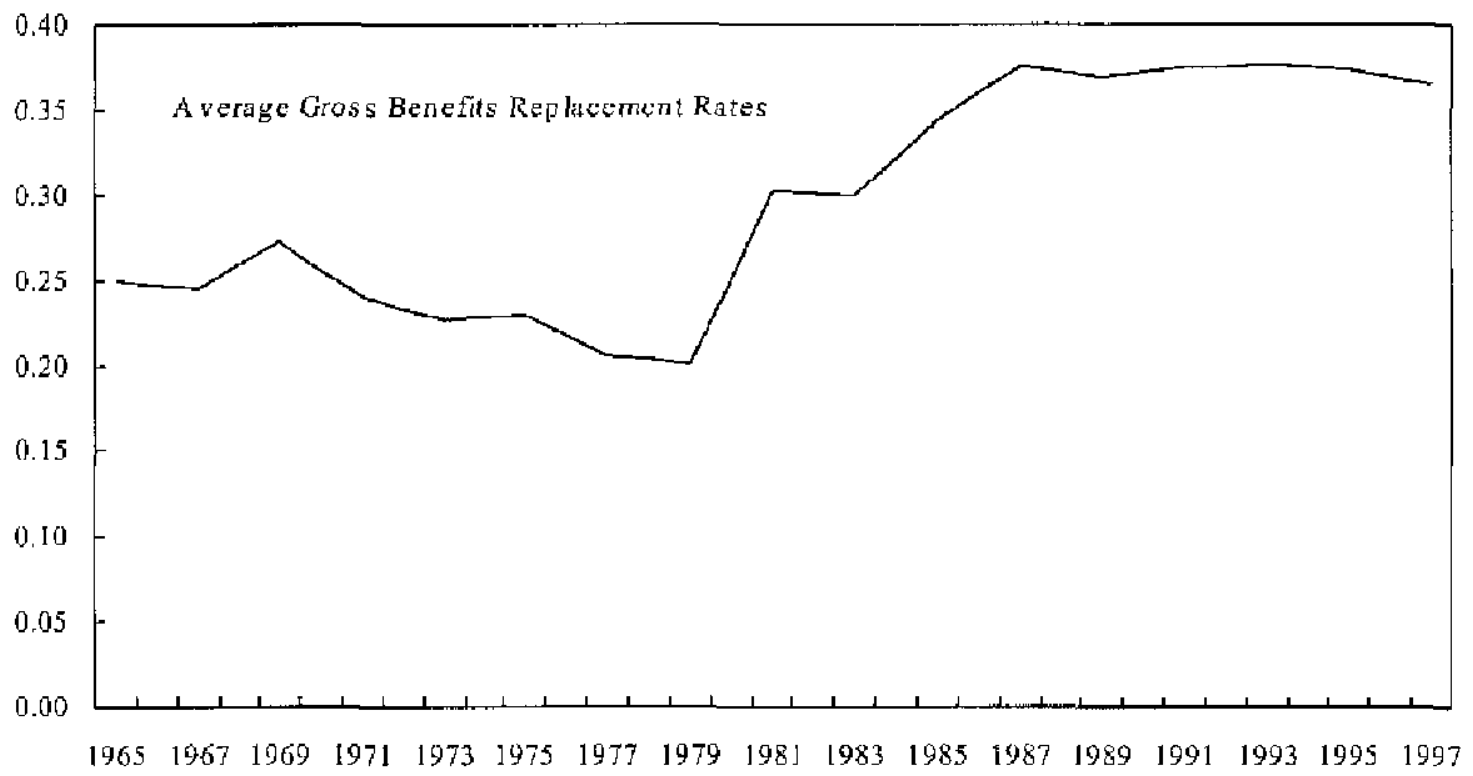

Soure: OECD tax and benefits database and staff cakulations. 
17. The exercise performed here does not pin down the possible sources for the changes in unions' preference or overall bargaining power. Structural changes in labor market institutions may be behind the shift in the wage curve although it is hard to measure institutional changes or their direct relationship to unions' behavior. ${ }^{14} \mathrm{Also}_{3}$ part of the observed wage moderation since 1996 might have been caused by negotiations within firms which adopted the 35-hour workweek following the introduction of the 1996, 1998 and 2000 laws. ${ }^{\text {is }}$

\section{CoNCLuSion}

18. During the 1990s, the growth rate of real hourly wages in France has fallen below the trend growth rate of total factor productivity. In a right-to-manage model in which firms and labor unions bargain over wages, but firms determine employment levels-a realistic approximation of French labor market institutions-such a wage moderation is consistent with an increase in preferences of workers toward employment or a reduction in union bargaining power. These changes would cause a downward shift in the relationship between wages and unemployment and an increase in employment given the state of labor demand.

Microeconometric estimations using annual household level survey data (Enquête Emploi) that allow the level of wages to be related to individual characteristics as well as local labor market conditions provide evidence of such an outward shift in the relationship between wages and unemployment that is independent of changes in labor demand, taxes and unemployment income. In the process, robust estimates of a wage curve are derived with an elasticity of wages with respect to the unemployment rate of -0.1 , in line with estimates found for several other countries.

${ }^{14}$ The OECD monitors the strictness of employment protection legislation (EPL) on a regular basis. In its latest analysis, the OECD claimed that France's EPL became more stringent in the $1990 \mathrm{~s}$ as a result of new limitations on fixed-term contracts and the operation of temporary work agencies. Besides the usual caveats that should accompany this type of analysis, it is important to note that significant other changes, such as the reduction of the standard workweek, are not captured by the OECD's EPL measure.

${ }^{15}$ Passeron (2000) shows that firms which adopted the 35-hour workweek following the 1996 and 1998 laws posted larger employment growth than other similar firms. Such a difference in behavior could have been caused by the reported moderate increase in wages that possibly did not offset gains in hourly productivity. 


\section{DETAILED INFormation ON THE ENQUÊTE EMPLOI}

19. The Enquete Emploi (EE) is an annual employment survey conducted by the Institut National de la Statistique et des Etudes Economiques (INSEE) in March of every year (except in 1999 when the survey was undertaken in January). The sample period used in this paper runs from 1990 through 2000 . Information for years prior to 1990 was not used due to the reporting of the wage variable in brackets as opposed to discrete numbers. The survey collects information of individuals at the household level on demographic characteristics (e.g., age, sex, marital status, number of children in the household), level of education, and labor market characteristics (e.g., labor force participation status, employment status, net monthly salary in the main job, number of hours worked in the main job during the week before the interview, industry and type of occupation) and the region of residence.

20. The dataset includes about 1.6 million observations for the population aged 15 years or more (about 146,000 observations, on average, for every year; see Table 4). Individuals between 15 and 64 years of age who reported positive net monthly salary in a regular job have been selected for the regression analysis. The selected sample excludes extreme observations, public sector employees, self-employed, apprentices, retired, inactive and those employed in the agricultural sector and military service. ${ }^{16}$ The paper departs from the convention of selecting prime-age male full-time workers with a view to controlling for the changing composition of the labor force by age, sex, employment status and other demographic and sectoral classification of occupation in the wage regression.

Table 4. France: Sizes of Full and Selected Samples

\begin{tabular}{ccc}
\hline Year & $\begin{array}{c}\text { Full sample } \\
\text { (15 years and older) }\end{array}$ & Selected sample \\
\hline 1990 & 136281 & 24209 \\
1991 & 137298 & 22833 \\
1992 & 141053 & 24001 \\
1993 & 146803 & 26005 \\
1994 & 151590 & 27111 \\
1995 & 151146 & 26845 \\
1996 & 150365 & 26799 \\
1997 & 148891 & 25901 \\
1998 & 149132 & 25700 \\
1999 & 148867 & 25055 \\
2000 & 148775 & 24892 \\
\hline
\end{tabular}

Source: Authorities, Erquête Emploi.

${ }^{16}$ Extreme observations are characterized by net salary that satisfies: $\mid$ Individual Salary - Median salary $\mid>3 \times\left(75^{\text {th }}\right.$ Percentile $-25^{\text {th }}$ Percentile $)$. 
21. The wage variable used here is the reported monthly salary net of social security contributions in the principal job (thus, it is the pre-income tax wage). Whenever the analysis refers to the annual salary, the monthly variable is multiplied by 12 . The annual labor earning variable is obtained by adding non-wage annual benefits to annual net salary. The hourly wage variable, on the other hand, has been calculated by dividing the net monthly salary by 4.33 and the number of hours worked in the main job in the week prior to the interview. Overtime hours are recorded in the weekly hours variable only when the individual worked more during the reference week than during a normal week. If the individual systematically works more than the legal working time (supplementary hours), these extra hours are not recorded separately. There is a potential measurement error in the weekly hours variable for those respondents who worked less than usual hours in the reference week due to illness, strike, weather condition, move into retirement or unemployment, or other plausible reasons for temporary drops in labor supply. 


\section{REFERENCES}

Blanchard, O., 1997, "The Medium Run," Brookings Papers on Economic Activity, 2, pp:89-158.

Unemployment," Journal of Economic Perspectives, Vol.11, No.1, pp.51-72.

Blanchflower, David G. and Oswald, Andrew J., 1994, The Wage Curve, MIT Press.

Card, D., 1995, "The Wage Curve: A Review," Journal of Economic Literature, Vol. XXXIII, June, pp.785-799.

Decressin, J., M. Estevão, P. Gerson and C. Klingen, 2001, "Job-Rich Growth in Europe, Background paper to the German, French, Italian and Spanish 2001 Article IV consultations, IMF.

Estevão, M., and N. Nargis, 2001, "Wage Moderation in France," Working Paper, International Monetary Fund.

Layard, R., S. Nickell and R. Jackman, 1991, Unemployment, Oxford, Oxford University Press.

Moulton, Brent R., 1986, "Random Group Effects and the Precision of Regression Estimates," Journal of Econometrics, August, 32(3), pp.385-97.

—_ 1990, "An Illustration of a Pitfall in Estimating the Effects of Aggregate Variables on Micro Units," Review of Economics and Statistics, May, 7292, pp.334-38.

OECD, 1999a, Benefits Systems and Work Incentives, OECD, Paris.

- 1999b, Employment Outlook, OECD, Paris.

__ 2001, Employment Outlook, OECD, Paris.

Passeron, V., 2000, "Les 35 Heures, l'Emploi et les Salaires," Premières Synthèses, DARES, December, no. 50.2 .

Pisani-Ferry, J., 2000, Plein Emploi, Conseil d'Analyse Economique, Paris. 